\title{
A Film-Philosophy of Ecology and Enlightenment by Rupert Read
}

\section{Mio Lindman}

Read, Rupert. A Film-Philosophy of Ecology and Enlightenment, London: Routledge, 2019, 231 pp.

For quite a long time now, postWittgensteinian philosophers have taken an interest in film; film not as the art of illusion but rather as examining reality, perception and self. Rupert Read has published on film before, but in his new book $A$ FilmPhilosophy of Ecology and Enlightenment, the scope is more political than before. The book displays attentive film-watching and it also engages in an interesting argument about film as self-reflection and as reflection on the ecological crisis. Through a reading of twelve films, Read attempts to show that films can make us attend to what we are so eager to ignore or even deny and that films can, in a way relevant in times of looming ecological crisis, make us question our lack of care, our having given up on this world.

The films Read draws on are refreshingly varied: he discusses arthouse films like Last Year in Marienbad, but also recent blockbusters such as Avatar. A firm belief in the liberatory dimension of, at least some, cinema, runs through the text. By "liberatory" Read means, in the vein of critical theory, liberation from a sense of world-alienation, but he also gives the concept of "liberation" a Wittgensteinian twist. The latter could be explained as making us give up a world-weary eagle-eye-perspective that scorns the rough ground. Read, through his choice of films, focuses on descriptions of what it is like to return from world-weariness to rejoice in the human world and earthbound life. He conjures these returnings as an intellectual and spiritual conversion. One of his most striking examples of a "return" is to be found in his chapter on Alfonso Cuarón's Gravity (2013), that he connects to the very first pages of Hannah Arendt's The Human Condition, in which she worries about our tendency to, in different ways, deny our earthboundedness. "Conjures" is, I think, the right word here, because the author is eager to bring out the moral force of film; the impact movies have 
on the viewer is not restricted to an isolated viewing experience.

The book consists of six chapters, each dealing with one main film and then one other to which it is compared. The first chapter, that deals with the animated Israeli film Waltr. with Bashir (2008, dir. A. Folman), sets the tone. Here, Read delves head-on into "therapeutic" film. The story is about an Israeli soldier talking to one of his friends who complains about nightmares. They are both veterans of the 1982 Lebanese war. What happened there, why can't Ari, the main character, remember what role he had in the Shabra and Shatila massacre? Read addresses questions of trauma and acknowledgment through a close reading of the film, along with the criticism it has received. He judges the form of Waltr, with Bashir, animation, to be all-important for bringing out the sense of the main character's disorientation and trauma.

No doubt, Read is a perceptive viewer. Often, his descriptions open up dimensions of the films discussed that unearth their existential seriousness. This is the case of, for example, his quite rich attempt to show that the Lord of the Rings-series (dir. P. Jackson) is not necessarily a romanticized celebration of war and honor, that it can be understood to be a depiction of the temptations of striving for power and safety. What to me had appeared to be a rather banal story turns out to contain the seeds of something more interesting, an allegorical exploration of in/sanity and power.
In other cases, I find that Read on the one hand fruitfully engages with the films he discusses and that he manages to describe the specific relation that is established between the particular film and this particular viewer. Read is good at pointing out the open-ended nature of the films he has chosen. He states that he does not want to treat films as philosophical arguments for the philosopher to dissect in a cool way. Rather, the way we engage with film is all-important. That is also why he lets his reflection on film be a reflection on the state of the world.

On the other hand, I find some of his readings too loose; his associations are most often intelligible, but in some cases they remain at the level of "associations" that do not deepen one's understanding of the film, or the state of the world. I would not say that his arguments are contrived, but the problem is rather that the readings of the films are sometimes not enhanced by his philosophical references, to Wittgenstein for example, and sometimes the Wittgenstein-inspired readings risk turning the discussion into theoretical arguments. I had this feeling in the chapter on Hiroshima Mon Amour and Last Year in Marienbad. I am also troubled by the tendency to treat the philosophy of Wittgenstein as being of a general "spiritual" kind, so that Read often makes Wittgenstein's philosophical insights look like very general existential teachings. This runs the risk of making the points in relation to the film lose their edge and become much too general existential and political exhortations. 
In the book, there are constant transitions from the philosophical to the psychological, and from the psychological to the political/ ecological. This can be eye-opening, such as in the case of his treatment of von Trier's Melancholia that he describes as a film about depression but also a film about what it means to start to find one's feet in the world. However, many of these transitions remain a bit too hasty. For example, in the middle of his chapter on Lord of the Rings, over just five pages, Read discusses madness, terrorism and the dynamics of power. I also find the use of diagnostic language (schizophrenia, psychosis, neurosis) too hasty in that the author many times moves very quickly from treating psychosis, for example, as a psychological illness to talking about it as a metaphor.

Read's effort to make the reader "wake up" by discussing films about "waking up" is challenging. I am sympathetic to Read's view of philosophy as being an intellectual and a personal affair, but his attempts to "wake the reader" often slide into repetitive patterns. The risk is that what he says will not shake anybody out of their lazy feeling of "yes, we all know this" and that, instead, what he says comes out as gestures, even though I do not doubt that his words are earnest. A tighter style and some more editing of the text could have helped. However, I also think my reaction reflects a real difficulty in philosophy that has to do with a desire to shake the reader by means of making her turn her gaze on herself and, as Read would like, to turn it back onto the world with a regained sense of hope. The tension I find in Read's book that might explain my unease with the effort to "wake us up" is, on the one hand, its care to engage with the specifics of the movies and his own way of experiencing them, and, on the other hand, his eagerness to draw out from these movies "vital 'timeless' wisdom for our time." (210) The challenge is how one can make one's experiences of cinema accessible for others, not just accessible in the sense of "intelligible" (which I think Read's book always is) but in a way that brings out how watching a film is a shared enterprise of thinking, feeling and engaging with the world. I would argue that this is no mere stylistic challenge, but rather that it belongs to the challenges of moral philosophy: what does it mean to invite others to see what I have seen, so that we can both engage in a common exploration of art and the world?

\section{Åbo Akademi University, Finland mio.lindman@abo.fi}

